УДК 378.016: [373.5.011.3-051:80]

DOI: 10.37026/2520-6427-2020-104-4-54-59
Леся ЗЛАТІВ,

кандидат педагогічних наук, доцент кафедри стилістики та культури української мови

Рівненського державного гуманітарного університету

\title{
ТРАНСФОРМАЦІЯ ЛІНГВОМЕТОДИЧНОЇ ПІДГОТОВКИ МАЙБУТНЬОГО ВЧИТЕЛЯ-СЛОВЕСНИКА В УМОВАХ ВИКЛИКІВ СЬОГОДЕННЯ
}

У статті проаналізовано наукові засади лінгвометодичної підготовки майбутнього вчителя-словесника в контексті ієрархічної тріади понять «професійна компетентність учителя-словесника», «методична компетентність учителя-словесника», «лінгвометодична компетентність учителя-словесника». Сформулювано авторське визначення поняття «лінгвометодична компетентність майбутнього вчителя-словесника». Виокремлено низку актуальних проблем, щчо постали в умовах трансформачійних прочесів у освітній галузі й поглибились під упливом викликів сьогодення, висловлено міркування щцодо шляхів розв'язання означених проблем, окреслено перспективні напрями трансформаџії лінгвометодичної підготовки майбутніх учителів-словесників.

Ключові слова: лінгвометодична підготовка учителя-словесника, професійна компетентність учителя-словесника, методична компетентність учителя-словесника, лінгвометодична компетентність учителя-словесника, трансформачія.

The article analyzes the scientific principles of linguistic and methodological training of a future philology teacher in the context of the hierarchical triad of concepts "professional competence of philology teacher», "methodological competence of philology teacher», "linguistic and methodological competence of philology teacher».

The author has formulated her own definition of "linguistic and methodological competence of a future philology teacher» as the ability to organise a high quality and responsibly approached process of teaching the native (official) language at a high scientific and methodological level, in institutions of different types of blended learning, including modeling lessons of different types and efficiently applying methods, techniques, tools and technologies of teaching the language, learning and implementing pedagogical innovations in the practice of language teaching, critically evaluating one's own experience as well as professionals'one, reflecting, creating modern and methodologically balanced educational content, including electronic one, learning and improving oneself in the context of life-long learning.

Additionally, this article highlights a range of actual problems which arose in the conditions of reforms, standardization of secondary school and higher Ukrainian language- based education, rapid advances in information and communications technology, introduction of new forms of receiving an education (distance, web, dual and mixed education), and were aggravatated under the influence of today's challenges. The author has expressed a range of opinions about the ways to solve the problems and outlined the perspective directions of transformation in linguistic and didactic training of future philologists, for example, a review of contents of educational training programs for experts majoring in the specialty 014 «Secondary education (Ukrainian language and literature)», and an increase in the number of methodologically and text-oriented courses; gradual introduction of measures, connecting with realisation of the mixed form of education and its technological support in an educational institution; organisation of the system of methodological competence development for all university lecturers; transformation of the system of methodological and linguistic training of future philology teachers.

Key words: methodological and linguistic preparation of a future philology teacher, professional competence of a philology teacher, methodological competence of a philology teacher, linguistic and methodological competence of a future philology teacher, transformation.

Постановка проблеми. В умовах трансформаційних процесів у галузі освіти, як-от реформування, стандартизація як шкільної, так і вищої україномовної освіти, бурхливий розвиток інформаційно-комунікаційних технологій, упровадження нових форм здобування освіти (дистанційної, мережевої, дуальної, а також змішаного навчання) та викликів сьогодення (пандемія, зовнішня агресія, світова економічна криза, процеси глобалізації та діджиталізації людства, постійного перегляду та переосмислення потребують проблеми професійної підготовки майбутнього вчителя-філолога.

Сучасний учитель-словесник повинен поєднувати декілька функційних образів: професійного філолога, методиста, психолога, педагога-вихователя, організатора, фасилітатора, дослідника, технолога, активного громадського діяча та ін. Він має володіти інноваційним і креативним мисленням, перспективними педагогічними технологіями, орієнтуватися в сучасному постійно змінному освітньому просторі, відповідально робити свій вибір, ефективно розв'язувати актуальні проблеми, бути активним суб' єктом особистісного розвитку й професійного зростання, а також патріотом своєї держави. 
Усе це зумовлює потребу в переосмисленні наукових засад професійної підготовки майбутнього вчителя-філолога, подальшого розроблення цієї проблеми на якісно новому рівні, із застосуванням інноваційно-трансформаційних підходів до організації цієї підготовки.

Аналіз наукових досліджень і публікацій. Проблема професійної підготовки фахівців у галузі філології охоплює широке коло питань та $є$ актуальною для вітчизняних і зарубіжних дослідників. Загалом питанням забезпечення якісної філологічної освіти присвячено чимало праць вітчизняних науковців (3. Бакум, Н. Босак, М. Вашуленко, Н. Голуб, Ж. Горіна, О. Горошкіна, Т. Донченко, С. Срмоленко, С. Караман, Л. Мацько, Н. Остапенко, М. Пентилюк, К. Плиско, О. Семеног, Т. Симоненко, С. Яворська та ін.).

Окремі аспекти професійної підготовки майбутніх учителів-словесників поставали предметом самостійних досліджень науковців, зокрема: педагогічні умови формування професійної компетентності й готовності філологів до професійної діяльності, самовдосконалення та професійного розвитку (I. Алєксєєва, В. Баркасі, Н. Білоус, О. Вовк, С. Данилюк, В. Демидова, В. Коваль, Н. Колесниченко, О. Матвєєва, Т. Мельник, О. Семеног, Т. Семенюк, В. Сидоренко, Т. Симоненко, Т. Стеченко, Ж. Таланова та ін.); лінгводидактичні, методичні та соціолінгвістичні основи професійної підготовки студентів-філологів (Н. Андронік, Р. Барч, О. Бігич, О. Бєссонова, Н. Бориско, М. Вашуленко, Т. Донченко, О. Ішутіна, О. Кучерук, Л. Мацько, Л. Морська, С. Ніколаєва, Н. Остапенко, Л. Паламар, М. Пентилюк, Л. Сімоненко, Л. Струганець, В. Студенкіна, Л. Черноватий та ін.).

Проте в умовах сьогодення виникають певні проблеми, які потребують переосмислення наукових засад професійної підготовки вчителів-філологів загалом та окремих ii складників зокрема.

Зважаючи на це, мета нашої статті - проаналізувати наукові засади лінгвометодичної підготовки майбутнього вчителя-філолога, виокремити актуальні проблеми, що постали в умовах трансформаційних процесів у освітній галузі й поглибилися під упливом викликів сьогодення, висловити міркування щодо шляхів розв'язання цих проблем та окреслити перспективні напрями трансформації лінгвометодичної підготовки майбутніх учителів-словесників.

Виклад основного матеріалу. Професійні характеристики сучасного педагога-словесника, на наше глибоке переконання, мають грунтуватися на компетентнісних засадах. Тому проаналізуємо наукові основи лінгвометодичної підготовки майбутнього вчителя-словесника в контексті ієрархічної тріади понять: «професійна компетентність учителя-словесника», «методична компетентність учителя-словесника» та «лінгвометодична компетентність учителя-словесника».

Поняття «професійна компетентність учителясловесника» $\epsilon$ предметом серйозного наукового осмислення. 3-поміж сучасних наукових пошуків на особливу увагу заслуговують праці української дослідниці О. Семеног, яка вперше ретроспективно проаналізувала національний досвід професійної підготовки вчителів-словесників, суттєво оновила методологію змісту й технології навчання, запропонувавши авторську модель системи професійної підготовки вчителів-філологів 3 урахуванням компетентнісно зорієнтованого підходу. Вчена визначає професійну компетентність учителя-словесника як «інтегральну особистісну якість, що включає педагогічну, психологічну, лінгвістичну, мовну, комунікативну, фольклорну, літературну, культурознавчу, педагогічну, психологічну, методичну, інформаційну, дослідницьку компетенції й виявляється на високому рівні готовності студентів-філологів до педагогічної діяльності» [9, с. 32-35].

Сучасні дослідники у своїх працях обгрунтовують також інші складники професійної компетентності, як-от: риторична (Н. Голуб, О. Горошкіна), технологічна, проєктна (К. Климова, О. Копусь, О. Кучерук, О. Любашенко, Н. Остапенко), українознавча, інтеракційна, етнологічна, міжкультурна, аксіологічна, прогностична (Т. Мельник), дискурсивна (дискурсна) (Ф. Бацевич, Л. Синельникова, Н. Остапенко, А. Нікітіна), предметно-фахова, особистісно-комунікативна, діяльнісно-технологічна (В. Коваль), комунікативно-когнітивна (О. Вовк, О. Горошкіна, М. Пентилюк, А. Нікітіна) та ін.

Майже всі дослідники у структурі професійної компетентності вчителя-словесника виокремлюють методичну компетентність. О. Семеног вважає, що основу методичної компетентності вчителя-словесника становлять знання методологічних і теоретичних засад методики навчання мови, літератури, концептуальних основ, структури та змісту засобів навчання, вміння застосовувати ці знання в педагогічній і громадській діяльності, виконувати основні професійно-методичні функції (комунікативно-навчальну, розвивальну, гностичну тощо), які дозволяють випускникам-філологам орієнтуватися в основних тенденціях, що визначають сучасний стан лінгвістичної, літературної освіти в закладах загальної середньої освіти (далі-33СО), в розширенні обсягу змісту навчального матеріалу у зв'язку із включенням нових дисциплін, посиленні принципів інтегративності, міжпредметної взаємодії, текстоцентричного підходу, опори на історію мови [9, с. 35]. В. Сидоренко відносить методичну компетентність до предметних компетентностей і визначає як таку, що включає засвоєння вчителем-словесником нових методичних та педагогічних ідей, освітніх підходів (компетентнісного, особистісно зорієнтованого, комунікативно-діяльнісного, соціокультурного) і технологій (інтерактивних, розвивальних та ін.), володіння інноваційними методами, формами та способами організації навчання [10, с. 11-17]. О. Горошкіна дає таке визначення методичної компетентності майбутнього вчителя-філолога: «Складне професійно-особистісне утворення, що поєднує особистісні, професійні особливості, освітній результат, професійний досвід, цінності й реалізується в навчальній діяльності» [1, с. 4].

У структурі методичної компетентності майбутнього вчителя-філолога лінгводидакти виділяють такі складники: загальнометодична (дидактична) компетентність, що включає такі компетентності, як мотиваційна, когнітивна, інформаційна, комунікативна та соціальна; лінгвометодична компетентність (далі - ЛМК), яка розмежовується на лінгводидактичну компетентність та конкретно-методичну (часткову) компетентність і містить знання вчителя-словесника про закономірності засвоєння мови, методи, 
прийоми й технології тї навчання, певні труднощі здобувачів середньої освіти у процесі опанування навчального матеріалу, відбір на цій основі принципів і методів, форм і засобів навчання $[4 ; 7 ; 11]$.

На сьогодні у вітчизняній науці не вироблено єдиного підходу до визначення поняття «лінгвометодична компетентність». Науковці по-різному тлумачать її сутність, структуру, окреслюють розбіжності у назві цього складника професійно-педагогічної компетентності вчителя-словесника. Так, Н. Остапенко розрізняє поняття «лінгводидактична компетентність» та «лінгвометодична компетентність». Першу, лінгводидактичну компетентність, дослідниця трактує як володіння випускниками наборами знань, умінь, навичок і досвідом оцінного ставлення до предмета, змісту та структури мовознавчої дисципліни, використання принципів, методів, прийомів, засобів та форм навчання, виділяючи у іiі структурі 16 компетенцій (інформаційну, мотиваційну, логічну, методологічну, особистісну (процесуальну), технологічну, комунікативну, проєктивну, рольову, аксіологічну (культурологічну), соціальну, креативну, стратегічну, діагностичну, дискурсивну, рефлексивну), а другу, лінгвометодичну компетентність, - як володіння випускниками спеціально структурованими наборами знань, умінь, навичок, досвідом оцінного ставлення до змісту, структури, форми навчання мови, принципів, методів і прийомів, засобів, а також специфічних особливостей кожного із мовознавчих розділів, уведених до чинної шкільної програми або програми закладу вищої освіти (далі-3ВО). На думку вченої, іiі формування відбувається паралельно на заняттях із дисциплін психолого-педагогічного та методичного спрямування на трьох рівнях: феноменологічному, методологічному та креативному [7, с. 14-16].

O. Копусь, досліджуючи фахову підготовку магістрів-філологів, лінгводидактичну компетентність розглядає як «володіння магістрантом сукупністю знань, умінь, навичок і досвідом оцінного ставлення до суб'єкта, об'єкта, предмета, змісту та структури мовознавчих і лінгводидактичних дисциплін, умінням реалізовувати принципи, методи, прийоми, засоби та форми навчання, що являють собою інтегровану характеристику якості особистості майбутнього магістра-філолога» [5, с. 85]. В. Студенікіна характеризує лінгводидактичну компетентність як компонент лінгвометодичної компетентності вчителя-словесника в складі його методичної компетентності [13].

Нам імпонує наукова позиція О. Ішутіної, яка вважає, що різні дефініції лінгвометодичної (лінгводидактичної) компетентності лише доповнюють одна одну, акцентуючи увагу на різних сторонах одного поняття. Учена тлумачить ЛМК як «здатність учителя продуктивно вирішувати професійні завдання в галузі мовної освіти школяра на основі системи знань 3 української мови та методики іiі викладання через усвідомлення метапредметної функції рідної мови та їі статусу як національно-культурного феномену; сформованість ціннісних орієнтацій педагога як людини 3 високою духовно-моральною культурою; готовність і прагнення до професійного самовдосконалення й сприйняття передового науково-методичного досвіду в галузі навчання рідної мови» [3, с. 68] і виокремлює такі основні іiі компоненти: професійно-комунікативний, психолого-педагогічний, предметний (або спеціальний), діагностичний, інформаційно-комунікаційний, акмеологічний [3, с. 69-70].
Аналіз проєкту Стандарту вищої освіти зі спеціальності 014 «Середня освіта (українська мова та література)» дозволив дійти висновку, що більшість фахових компетентностей, які необхідно сформувати у майбутнього вчителя-філолога, пов'язана саме 3 лінгвометодичною підготовкою, наприклад: здатність формувати в учнів предметні компетентності; застосовувати у власній практичній діяльності сучасні підходи до викладання української мови на підставі передового українського й міжнародного досвіду, ефективні методи й освітні технології навчання; здійснювати об'єктивний контроль і оцінювання рівня навчальних досягнень учнів; здатність використовувати когнітивно-дискурсивні вміння, спрямовані на сприйняття й породження зв'язних монологічних і діалогічних текстів в усній і письмовій формах, володіти методикою розвитку зв'язного мовлення учнів у процесі говоріння й підготовки творчих робіт; здатність до критичного аналізу, діагностики та корекції власної педагогічної діяльності, оцінки педагогічного досвіду (як вітчизняного, так і зарубіжного); здатність виконувати власне дослідження (проєкт), узагальнювати й оприлюднювати результати діяльності з розроблення актуальної проблеми (у фахових виданнях, виступах тощо); застосовувати елементи теоретичного й експериментального дослідження у професійній діяльності; доцільно використовувати й створювати сучасне навчально-методичне забезпечення для проведення занять [12].

Аналіз наукової літератури, нормативних документів, а також багаторічний досвід викладання методично зорієнтованих дисциплін на філологічному факультеті («Методика навчання української мови», «Шкільний курс української мови та методика його викладання», «Методика профільного навчання української мови та літератури», «Педагогічний дискурс викладача-мовника», «Лінгвістика тексту у шкільному курсі рідної мови») дозволяє нам виокремити низку актуальних проблем, пов'язаних із лінгвометодичною підготовкою майбутніх учителів-філологів. Згрупуємо їх відповідно до моделі лінгвометодичної компетентності, запропонованої О. Ішутіною [3]:

\section{1. Професійно-комунікативний компонент.} Недостатній рівень мовно-мовленнєвих та дискурсно-комунікативних знань і вмінь (про систему сучасної української літературної мови, мовні норми й правила етикету, види та жанри мовлення, закони та правила, стратегії й тактики спілкування, особливості педагогічного дискурсу тощо) суттєво знижує можливості майбутнього вчителя-філолога повноцінно здійснювати професійне (педагогічне) спілкування у навчально-освітньому середовищі для досягнення поставлених цілей та очікуваних результатів.

2. Психолого-педагогічний компонент. Недостатній рівень знань закономірностей психологічного розвитку школярів різного віку породжує невміння мотивувати здобувачів освіти до опановування рідної мови й мовлення, розвитку їхньої мовної й мовленнєвої компетентностей, правильно формулювати мету, завдання й очікувані результати навчання, підбирати освітній контент для учнів певного класу, формулювати завдання різного рівня складності, вибудовувати педагогічно обгрунтовані стосунки з усіма суб'єктами освітнього процесу, працювати 3 обдарованими учнями та такими, що мають обмежені можливості. 
3. Предметний (або спеціальний) компонент.

Недостатній рівень знань і вмінь із теорії й практики сучасної української мови та методики ії навчання або суттєві прогалини в знаннях, зумовлені суб'єктивними чи об'єктивними чинниками, не дозволяють студентам повною мірою зануритись у лінгвометодичний контекст професійно зорієнтованої ситуації. Наприклад, якщо студент не володіє теорією тексту (бо в освітній програмі не передбачені такі курси, як «Текстознавство», «Теорія тексту», «Лінгвістичний аналіз тексту», «Лінгвістика тексту» та ін.), він не спроможний моделювати уроки на засадах текстоцентризму, здійснювати різні види аналізу тексту, повноцінно комунікувати в педагогічному дискурсі. Це породжує низку інших проблем: невміння працювати з інформацією навчально-мовного призначення, оцінювати її якість та лінгводидактичний потенціал, створювати тексти-препарати, адаптовуючи їх до конкретних дидактичних завдань тощо.

Труднощі засвоєння студентами лінгводидактичного інструментарію виникають і через розбіжності в трактуванні їх різними науковцями, нечіткість визначень або складність понять (наприклад, у сучасній лінгводидактиці досить умовні межі між поняттями підходи, принципи, аспекти навчання мови, паралельно функціюють у науковій літературі термінологічні сполучення інтерактивні методи, прийоми та технології навчання, методи і технологї проблемного навчання, проблемний підхід тощя), і через наявність значної кількості класифікацій методів навчання, типів уроків, технологій та відсутність єдиної сучасної класифікації.

Також серйозною проблемою ми вважаємо наявність «готової» методичної продукції (розробки уроків, збірники текстів із завданнями до них). 3 одного боку, студент має можливість запозичити передовий педагогічний досвід, а 3 іншого - освітній контент часто не $є$ методично виваженим, потребує глибокого аналізу й перероблення з урахуванням конкретних педагогічних умов. Крім того, чужі конспекти, реферати, проєкти, взяті з інтернет-ресурсів, провокують переважання у здобувачів філологічної освіти репродуктивного та імітаційного типів мислення над аналітичним, критичним, творчим, порушення правил академічної доброчесності.

4. Діагностичний компонент. Спостерігаючи за студентами під час практичних і лабораторних занять, педагогічної практики, ми відзначаємо недостатній рівень умінь оцінювати результати навчальної діяльності школярів, доречно добирати диференційовані завдання, складати тести різних рівнів складності та проводити контрольні заходи.

5. Інформаційно-комунікаційний компонент. Невисокий рівень у майбутніх учителів-філологів умінь працювати з інформацією навчально-лінгвістичного призначення, незнання типології електронної та мультимедійної дидактичної продукції, інтернет-ресурсів навчально-мовного характеру, незнання критеріїв оцінки їхньої якості та методики використання електронних засобів навчання мови на уроках та в позакласній роботі, відсутність навичок самостійно продукувати електронну й мультимедійну продукцію дидактично-комунікативного призначення за допомогою ПК суттєво знижує рівень організації дистанційного навчання мови в умовах змішаного навчання.
6. Акмеологічний компонент. За результатами багаторічних спостережень у значної частини майбутніх філологів констатуємо низький рівень володіння прийомами самоаналізу, взаємоаналізу та рефлексії, особистісного самовираження й саморозвитку, бажання самовдосконалюватися, підвищувати рівень власної лінгвометодичної компетентності за допомогою опрацювання сучасної науково-педагогічної та методичної літератури.

Наведемо деякі міркування щодо шляхів вирішення виокремлених вище проблем та окреслимо пріоритетні напрями трансформації лінгводидактичної підготовки майбутніх учителів-філологів, що видаються нам перспективними:

1. У контексті вимог стандартизованої вищої освіти виникає потреба у перегляді змісту освітніх програм підготовки фахівців зі спеціальністю 014 «Середня освіта (українська мова та література)» та збільшенні питомої ваги методично зорієнтованих та текстоорієнтованих курсів (наприклад, «Методика профільного навчання української мови та літератури», «Педагогічний дискурс вчителя-словесника», «Дидактична текстологія», «Лінгвістика тексту») i педагогічної практики у нормативному блоці дисциплін (відповідно до очікуваних результатів навчання за освітньою програмою). Також доречним $є$ уведення до блоку вибіркових дисциплін курсів, спрямованих доповнити, розширити загальні й фахові компетентності здобувачів вищої освіти і одночасно поглибити лінгвометодичну підготовку майбутнього вчителя-словесника (наприклад, «Публічне мовлення», «Педагогічна риторика», «Основи медіаграмотності», «Лінгвістична конфліктологія», «Лінгвістика впливу»). Важливо, щоб серед них були інтегровані навчальні дисципліни, серед яких: «Вивчення української мови та літератури в ліцеях, гімназіях, колегіумах», «Перспективні технології навчання української мови та літератури в 33СО», «Комп'ютерна лінгводидактика», «Драматичне і музичне мистецтво в навчанні мови», «Психолінгвістичні засади навчання мови» та ін.

2. Виклики сьогодення сприяли появі нових форм здобування освіти (дистанційної, мережевої, дуальної), а також упровадженню змішаного навчання. Як показала практика, чимало викладачів і здобувачів освіти виявилися не готовими до змішаної форми навчання, особливо дистанційної в умовах карантину (переважно через невисокий рівень володіння інформаційно-комунікаційними технологіями, відсутність сучасних гаджетів, відповідних електронних підручників, посібників, методичних рекомендацій для проведення лекцій, практичних і лабораторних занять в онлайн-режимі, контролю та корекції знань, організації практик дистанційно). Якщо в закладі освіти немає цілісного розуміння, як відбувається освітній процес у дистанційних умовах, а кожен викладач використовує власний набір засобів навчання, відсутня можливість контролю якості навчання та методичних матеріалів, а також системна технічна й методична підтримка викладачів і здобувачів вищої освіти, то, зрозуміло, реалізація змішаного навчання носить хаотичний характер, а якість навчання є невисокою.

Шлях розв'язання цієї проблеми ми вбачаємо, услід за авторами «Рекомендацій щодо впровадження змішаного навчання у закладах фахової передвищої 
та вищої освіти», у послідовному впровадженні в закладі освіти системи заходів: 1) демонстрація готовності керівництва закладу до підтримки, витрат, змін у структурі закладу освіти та їхня ініціація (узгодження реалізації змішаного навчання зі стратегією розвитку закладу, врегулювання всіх його аспектів через прийняття пакета документів, аналіз поточної ситуації, з'ясування проблемних питань, створення робочих груп, визначення ключових учасників та окреслення зон їхньої відповідальності, виділення фінансових, матеріальних та людських ресурсів для виведення змішаного навчання на системний рівень); 2) налагодження двосторонньої комунікації між викладачами, працівниками кафедр і деканатів, студентами та стейкхолдерами (зацікавленими особами), кооперативна взаємодія усіх викладачів, які формують групу забезпечення освітньої програми (практикування інноваційних колективних і групових форм методичної роботи задля оптимізації змісту та обсягу дисциплін, їхньої інтеграції, адаптування до умов змішаного навчання); 3) організація системної підтримки (організаційної, методичної, технічної, психологічної) всіх учасників освітнього процесу та технологічне забезпечення системи змішаного навчання (вибір навчальної платформи й інтегрування iii iз внутрішніми інформаційними системами); 4) підвищення кваліфікації співробітників та викладачів; 5) систематичний моніторинг якості освітніх програм через анкетування здобувачів вищої освіти, викладачів, співпрацю зі стейхолдерами; систематичне оновлення бази вибіркових дисциплін (з урахуванням досягнень сучасної науки, наукового потенціалу випускових кафедр, умов змішаного навчання); внесення змін у навчальні плани; 6) створення навчального контенту курсів і дисциплін, оцінка його якості, проведення планового оновлення та оптимізації [8].

3. Лінгвометодична підготовка майбутнього вчителя-філолога значною мірою залежить не лише від рівня інформаційно-комунікаційної, а й від методичної компетентності викладачів. Цілком погоджуємось iз позицією Т. Дятленко, яка вважає, що методична компетентність - базова якісна характеристика викладача ЗВО. Її показниками є чітке визначення орієнтирів, тобто кінцевого результату навчання здобувачів вищої освіти; демонстрація взірця професіоналізму у своїй роботі; мотивування й організація ефективної діяльності студентів; знання й упровадження нових освітніх технологій, максимально адаптованих до специфіки навчальних дисциплін, які викладає, та власного досвіду; орієнтація на зв'язок теорії й практики задля розвитку активної професійної позиції та дієвого мислення майбутніх учителів-філологів; забезпечення зворотного зв'язку в навчанні через різні види контролю й самоконтролю; здатність до аналізу й самоаналізу освітньої діяльності, систематичне дослідження результатів власної праці через поетапну й підсумкову діагностику рівня якості знань і вмінь студентів й за потреби корекції власної педагогічної діяльності [2, с. 11].

Тому всім викладачам філологічних дисциплін варто систематично переглядати свій лінгвометодичний інструментарій, суттєво його оновлювати, доповнювати задля того, щоб мотивувати здобувачів філологічної освіти до активної освітньої діяльності, рефлексії, особистісного самовираження й саморозвитку, бажання самовдосконалюватися, щоб запобігати переважанню в них репродуктивного та імітаційного типів мислення над аналітичним, критичним, креативним, щоб не допускати порушень правил академічної доброчесності. Рівень сформованості фахових і загальних компетентностей майбутніх філологів залежить від того, як сформульоване кожне завдання, які теми запропоновані для обговорення проєкту, які методи, прийоми чи технології застосовані для опанування теорії та практики дисципліни й оцінювання результатів освітньої діяльності студентів. Кожен викладач мимоволі стає взірцем для професійного наслідування.

4. Щодо формування лінгвометодичної компетентності в системі професійної підготовки майбутнього вчителя-філолога, то вона також потребує переосмислення та якісних змін. Безперечно, стрижнем професійної лінгвометодичної підготовки є орієнтація на формування професійно-комунікативної компетентності майбутнього вчителя-словесника, адже слово вчителя - це основний інструмент його професійної діяльності. У центрі навчання української мови на всіх освітніх етапах $є$ мовна особистість - людина, яка знає мову, володіє багатством іiі виражальних засобів, продукує мовлення в різних життєвих ситуаціях, шанує іiі, любить і дбає про іiі збереження й розвиток. Проте власне лінгвометодична компетентність безпосередньо формується в майбутніх учителів-словесників на заняттях із методично зорієнтованих дисциплін, де закладається здатність засвоювати та втілювати нові методичні й педагогічні ідеї, освітні підходи, аналізувати труднощі в опануванні учнями мови й добирати шляхи їх подолання, формується початковий досвід застосування інноваційних методів, форм і способів організації навчання на уроках української мови в школах різних типів, здатність змінювати досвід методичної діяльності, що перестає бути продуктивним за певних педагогічних умов, здатність до професійної рефлексії, відкритості до змін та новацій Нової української школи.

Аналіз найновіших досліджень свідчить про те, що лінгводидакти [3; 5-7] віддають перевагу технологічному підходу у формуванні лінгвометодичної компетентності, що передбачає формулювання мети, завдань, змісту, вибір методів, форм, засобів, врахування педагогічних умов та результатів моніторингу. Наприклад, О. Ішутіна рекомендує традиційні методи (опитування, бесіда, колоквіум, самостійна робота) поєднувати з інноваційними (портфоліо, ділова гра, інтерактивні й інформаційно-комунікаційні, тестування) та специфічними (спостереження й аналіз лінгвометодичної діяльності, моделювання, тренувальна лінгвометодична діяльність у реальних умовах), а також використовувати такі форми роботи, як проблемні лекції, дискусії, евристичні бесіди, ділові й симуляційні ігри, проєктна робота, науковий семінар, тестування, лінгвометодичне портфоліо $[3$, c. 186$]$.

Особливий акцент дослідники (К. Климова, Н. Остапенко, О. Любашенко, О. Копусь, О. Кучерук та ін.) роблять на проєктній діяльності в системі лінгводидактичної підготовки, пояснюючи її актуальність високим творчим потенціалом. 
Цілком погоджуємося з думкою О. Кучерук стосовно того, що завдання викладача - зробити проєктну діяльність студента (під час самонавчання, виконання наукового дослідження, на заняттях, у процесі активної педагогічної практики в школі) позитивно мотивованою на всіх етапах. Важливу роль у цьому відіграють методи навчання, зокрема: діалогування, аналіз конкретної навчально-виховної ситуації, педагогічне моделювання, метод проєктів, «мозковий штурм», рольова гра, дослідницькі методи, комплексний метод роботи 3 комп’ютером у гіперсередовищі та ін. [6, с. 12-13].

Унікальність проєктної діяльності в системі лінгводидактичної підготовки полягає в тому, що вона дозволяє сформувати в студентів цілу низку вмінь: уміння проблематизації (розглядати проблемну педагогічну ситуацію, виділяти іiі проблемні аспекти, формулювати основну проблему та проєктне завдання, пов'язане з розв'язанням цієї проблеми); уміння проєктування (цілевизначення, планування, моделювання, конструювання); уміння теоретико-практичної свідомої діяльності щодо реалізації проєкту (вміння змінювати напрям і трансформувати зміст проєктної педагогічної діяльності, варіативно використовувати різні способи професійно-педагогічної діяльності); уміння доцільного вибору й застосування комп'ютерних та інших технологій у проєктній діяльності, рефлексійні вміння (самоаналіз, поєднання суспільного досвіду з власним задумом, планом дій, роздум щодо проєктування власного інтелектуально-духовного потенціалу в освітне середовище) [6, с. 9].

Висновки. На основі аналізу наукових та нормативних засад лінгводидактичної підготовки майбутнього вчителя-словесника, проблем, що постали в умовах викликів сучасності, а також багаторічного досвіду викладання методично зорієнтованих дисциплін у закладі вищої освіти можемо сформулювати власне визначення лінгвометодичної компетентності майбутнього вчителя-словесника, під якою розуміємо здатність на високому науково-методичному рівні, якісно та відповідально організовувати процес навчання рідної (державної) мови в закладах різних типів в умовах змішаного навчання, що постійно змінюються, зокрема моделювати уроки різних типів, оптимально застосовувати методи, прийоми, засоби та технології навчання мови, засвоювати й утілювати в практику навчання мови педагогічні інновації, критично оцінювати чужий і власний педагогічний досвід, рефлексувати, створювати сучасний, методично виважений освітній контент, зокрема й електронний, навчатися й самовдосконалюватись упродовж усього життя.

Перспективи подальших досліджень вбачаємо у пошуку науково-методичних рішень для комплексного розв'язання актуальних проблем професійної підготовки майбутнього вчителя-словесника.

\section{СПИСОК ВИКОРИСТАНОЇ ЛІТЕРАТУРИ}

1. Горошкіна О. Етапи формування методичної компетентності майбутніх учителів української мови. Лінгводидактика: теорія, методика, досвід : зб. наук. пр. / ДВНЗ «Донбас. держ. пед. ун-т». Слов'янськ : ДДПУ. Вип. 3. 2013. С. 3-13.
2. Дятленко Т. Про підготовку майбутнього вчителя української мови й літератури до роботи в профільній школі в умовах сучасного педагогічного закладу. Украӥнська література в загальноосвітній школі. 2014. № 11. С. 11-13.

3. Ішутіна О. Технологія формування лінгвометодичної компетентності майбутнього вчителя української мови. Професіоналізм педагога: теоретичні ци методичні аспекти. 2017. Вип. 5 (2). C. 182-193. URL: http://nbuv.gov.ua/UJRN/ prptma_2017_5\%282\%29_21 (дата звернення: 11.10.2020).

4. Ішутіна О. Сутність і структура лінгвометодичної компетентності майбутнього вчителя рідної мови. Науковий вісник Ужгородського національного університету. Серія «Педагогіка, соиіальна робота». Слов'янськ, 2015. Вип. 36. С. 67-70. URL: https:// dspace.uzhnu.edu.ua/jspui/ bitstream/lib/pdf (дата звернення: 11.10.2020).

5. Копусь О. А. Теоретико-методичні засади формування фахової лінгводидактичної компетентності майбутніх магістрів-філологів: дис. ... доктора пед. наук : 13.00.02. Одеса, 2013. 472 с.

6. Кучерук О. Актуальні проблеми філологічної і лінгвометодичної підготовки майбутніх учителів. Лінгводидактичні аспекти фахової підготовки майбутнього вчителя : зб. наук. пр. VI Всеукр. наук.-метод. семінару викладачів і студентів (м. Житомир, 27 березня 2014 р.) / за ред. К. Я. Климової. Житомир : Вид-во ЖДУ ім. І. Франка, 2014. С. 5-14.

7. Остапенко Н. М. Теоретичні і методичні засади формування лінгводидактичної компетентності у майбутніх учителів української мови і літератури : автореф. дис. ... доктора пед. наук : 13.00.02 «Теорія та методика навчання (українська мова)». Київ, 20010. 37 с.

8. Рекомендації щодо впровадження змішаного навчання у закладах фахової передвищої та вищої освіти. URL: zmishanenavchannia-bookletspreads-2. pdf (дата звернення: 05.10.2020).

9. Семеног О. Професійна підготовка майбутніх учителів української мови і літератури : монографія. Суми : ВВП «Мрія-1» ТОВ, 2005. 404 с.

10. Сидоренко В. Модель професійної компетентності вчителя української мови і літератури в контексті впровадження компетентнісного підходу. Наукова скарбниия освіти Донеччини : наук.-метод. журн. Донецьк, 2010. № 2. С. 11-17.

11. Сімоненко Л. Методична компетентність як складник професійної компетентності вчителя української мови. Науковий вісник Донбасу. 2013. № 2. URL : http://nbuv.gov.ua/jpdf/nvd_2013_2_28.pdf (дата звернення: 09.10.2020).

12. Стандарт вищої освіти України (проєкт). Спеціальність 014.01 «Середня освіта (українська мова та література)». Київ, 2016. URL: 014.01-serednyaosvita-ukr.-mova-i-1-ra-bakalavr.pdf (дата звернення: 05.10.2020)

13. Студенікіна В. Лінгводидактична компетентність учителів української мови в структурі методичної. Вісник ЛНУ імені Тараса Шевченка. 2010. Ч. 1. № 22 (209). C. 85-90. URL: http://archive.nbuv.gov.ua/ portal/Soc_Gum/ Vlush/Ped/2010_22_1/12.pdf (дата звернення: 09.10.2020).

Дата надходження до редаки̧ї: 20.11.2020 p. 